\title{
老人基本健診におけるアポ蛋白測定の意義
}

\begin{tabular}{|c|c|c|c|c|}
\hline 文俊1) & 俊哉1) & 鈴木 & 善幸1) & 丸ん \\
\hline 政晴1) & 良光 ${ }^{1)}$ & 小沢 & 吉郎1) & 伊萠 \\
\hline 聡 2 & 並木美佐子2) & 秋山 & 俊彦2) & \\
\hline
\end{tabular}

老人及び住民基本健診において，血清総コレステロ ール (TC), 中性脂肪, HDL コレステロール (HDLC) 及びアポ蛋白 6 項目を測定し, その有用性につき検 討した。対象は新潟県六日町城内地区における, 住民 及び老人基本健診受診者 897 名で男性 304 名, 女性 593 名, 年齢は 36 才から 90 才まで平均 58.3 才であっ た。禁食採血群は 329 名であり, 食後採血群は 568 名 であった。基本健診結果にて異常なしと判定された正 常群の TC 平均值は $197 \mathrm{mg} / \mathrm{dl}$ で, 男は 40 代をピー クに加齢とともに若干低下傾向にあり, 女性は加齢と ともに上昇していた。HDL-Cの平均值は $56 \mathrm{mg} / \mathrm{dl}$ で，女性の 50 代は 60 代に比べ有意に高值を示した以 外, 加齢による変化を認めなかった。動脈硬化指数
(AI) は $2.0 \pm 0.9$, アポ B とアポ A-1の比 (B/A-1) は $0.60 \pm 0.16$ であり,どちらも TC と正の相関を認め たが，TC が正常で AI，B/A-1 が異常值を示す例が存 在した。なお $\mathrm{AI}$ と $\mathrm{B} / \mathrm{A}-1$ は強い正の相関を認めた。 肥満度 $20 \%$ 以上の肥満群とそれ以下の正常群の血清 脂質を比較したところ，TC は有意差を認めなかった が, HDL-C は前者が有意に低下し, AI と B/A-1 は有 意に上昇していた。禁食採血群と食後採血群の血清脂 質の值に有意差は認めなかった。以上より, 血清アポ 蛋白は食事の影響を受けにくく, また大量自動化測定 が可能であり，健診におけるスクリーニング検査とし て有用であると考えられた。

\section{Significance of the Measurement of Apoproteins in a Medical Examination}
1）新潟県立六日町病院内科
2) 同検査科 